\title{
HUBUNGAN INTENSITAS PENERANGAN DENGAN KELELAHAN MATA PADA PENGRAJIN BATIK TULIS
}

\author{
Nina Wiyanti, Tri Martiana \\ Departemen Keselamatan dan Kesehatan Kerja \\ Fakultas Kesehatan Masyarakat Universitas Airlangga \\ E-mail: ninawiyanti@yahoo.com
}

\begin{abstract}
One of eye's health problems that can be experienced by batik artisans are eyestrain. There are many factors that can cause eyestrain, one of them is the intensity of the illumination. This study aimed to analyze the relationship between the intensity of illumination with eyestrain on batik artisans. This type of research is descriptive observational study with cross sectional design. This research was conducted in nine home industry batik which is in the area of Kampung Batik Jetis Sidoarjo. Data obtained by direct measurement, observation, interviews, and see the monument which contains the history of the Jetis batik village. The results showed that the intensity of illumination in some Jetis batik home industry does not reach the standards of the majority of the UNEP (500 lux). The craftsmen who experience eyestrain or not, the amount is balance. Based on the results of the statistical test known that the value of Cramer's V coefficient is 0.905, which means the intensity of illumination with eyestrain has a very strong relationship level. The conclusion is, the intensity of the light which majority does not reach the standards had a very strong relationship with eyestrain. It is recommended to improve workplace hygiene lighting installation (including lamps), perform color settings and decorations workplace, using natural light as much as possible, and perform eye exams to the eye doctor regularly. Especially if the batik artisan's eyes look red, watery, and itchy and feeling frequent headaches.
\end{abstract}

Keywords: intensity of illumination, eyestrain

\begin{abstract}
ABSTRAK
Gangguan kesehatan mata yang dapat dialami oleh pengrajin batik tulis adalah kelelahan mata. Terdapat banyak faktor yang dapat menyebabkan timbulnya kelelahan mata, salah satu diantaranya yaitu intensitas penerangan. Tujuan dari penelitian ini adalah untuk menganalisis hubungan intensitas penerangan dengan kelelahan mata pada pengrajin batik tulis. Penelitian ini dilakukan di sembilan home industry batik tulis yang berada di daerah Kampung Batik Jetis, Sidoarjo. Jenis penelitian yang digunakan adalah penelitian deskriptif observasional dengan rancang bangun cross sectional. Penelitian ini dilakukan di sembilan home industry batik tulis yang berada di daerah Kampung Batik Jetis, Sidoarjo. Data diperoleh dengan cara pengukuran secara langsung, observasi, wawancara, dan melihat tugu yang berisikan sejarah kampung batik Jetis. Hasil penelitian menunjukkan bahwa intensitas penerangan di beberapa home industry batik tulis Jetis mayoritas tidak memenuhi standar UNEP (500 lux). Pengrajin yang mengalami kelelahan mata maupun yang tidak jumlahnya seimbang. Hasil uji statistik menunjukkan bahwa nilai dari koefisien Cramer's $V$ sebesar 0,905. Hal ini menunjukkan bahwa antara intensitas penerangan dengan kelelahan mata memiliki tingkat hubungan yang sangat kuat. Kesimpulannya intensitas penerangan yang mayoritas tidak memenuhi standar memiliki hubungan yang sangat kuat dengan timbulnya kelelahan mata. Saran agar meningkatkan kebersihan instalasi penerangan tempat kerja (termasuk lampu), melakukan pengaturan warna dan dekorasi tempat kerja, pemanfaatan cahaya alami semaksimal mungkin, serta melakukan pemeriksaan mata ke dokter mata secara teratur. Terutama jika mata terlihat merah, berair, dan terasa gatal serta sering mengalami sakit kepala.
\end{abstract}

Kata kunci: intensitas penerangan, kelelahan mata

\section{PENDAHULUAN}

Industri batik di Indonesia kini mulai berkembang hingga mencapai pasar internasional. Hal ini terbukti dengan pengakuan yang diberikan oleh UNESCO pada tahun 2009 yang memasukkan batik ke dalam Representative List of the Intangible Cultural Heritage of Humanity. Terdapat berbagai macam cara untuk membuat pola pada batik. Mulai cara yang sederhana hingga cara yang modern dengan menggunakan alat yang canggih. Tentunya dari berbagai cara tersebut memiliki kekurangan dan kelebihan masing-masing. Salah satu cara pembuatan pola pada batik yang masih sederhana yaitu dengan menggunakan canting.

Kelebihan dari batik tulis sendiri yaitu polanya lebih terlihat seperti bentuk asli dan warnanya cenderung relatif bertahan dalam jangka waktu yang lama (tidak mudah cepat pudar). Namun, batik tulis 
juga memiliki kekurangan yaitu harganya relatif lebih mahal dibandingkan batik lainnya dan proses pembuatannya pun relatif lebih lama. Terdapat berbagai macam batik tulis di Indonesia. Di mana tiap pola dan corak batik tulis tergantung dari daerah asalnya. Sehingga dari pola dan coraknya saja dapat diketahui dari mana asal daerah pembuatannya. Batik tulis Jetis, Sidoarjo merupakan salah satu batik tulis yang ada di Indonesia. Kekhasan dari batik tulis Jetis terletak pada warnanya yang mencolok. Motif dari batik tulis Jetis, Sidoarjo diantaranya abangan dan ijo-ijoan, motif beras kutah, motif krubutan, motif burung merak, dan motif lainnya seperti kembang bayem, pecah kopi dan kembang tebu.

Penglihatan merupakan salah satu fungsi pekerjaan yang sangat penting untuk dijaga dan dirawat oleh para pengrajin batik tulis dalam melakukan pekerjaannya. Hal ini karena pada industri batik tulis, ketepatan dan ketelitian mata merupakan kunci keberhasilan pengrajin dalam membuat suatu karya seni. Pada saat pengrajin batik tulis melakukan proses membatik, apabila dalam melakukan pekerjaannya dirasa kurang jelas, biasanya pengrajin batik tulis tersebut akan mendekatkan matanya ke objek (pekerjaannya) untuk menggoreskan coretan warna pada motif yang telah dibuat dengan canting yang sudah berisi pewarna khusus batik agar hasilnya sesuai garis motif dan tidak meleber.

Kondisi seperti ini membuat mata pengrajin tersebut harus berakomodasi lebih kuat lagi dan melakukan upaya mata yang berlebihan. Apabila hal ini dilakukan dalam jangka waktu yang relatif lama maka dapat menyebabkan kelelahan mata. Berdasarkan survei yang dilakukan oleh American Optometric Association (AOA) tahun 2004, membuktikan bahwa 61\% masyarakat Amerika mengalami gangguan kesehatan terutama pada fungsi mata akibat bekerja (Hanum, 2008). Kelelahan mata dapat terjadi apabila mata difokuskan pada objek yang berjarak dekat dalam kurun waktu yang relatif lama karena otot-otot mata harus bekerja lebih keras untuk melihat objek yang berjarak sangat dekat, terutama jika disertai dengan penerangan yang kurang memadai.

Beberapa gejala awal dari kelelahan mata diantaranya mata terasa kering, mata terasa terbakar, pandangan menjadi kabur, penglihatan menjadi ganda, sakit kepala, nyeri pada leher, bahu dan otot punggung (Hanum, 2008). Timbulnya kelelahan mata dipengaruhi oleh berbagai macam faktor, yang berasal dari pekerja maupun lingkungan kerja. Faktor pekerja yang menimbulkan kelelahan mata diantaranya usia, lama kerja, dan masa kerja. Faktor lingkungan yang dapat menimbulkan kelelahan mata yaitu intensitas penerangan.

Berdasarkan survei pendahuluan yang sudah dilakukan pada bulan Oktober 2014 menunjukkan bahwa rata-rata intensitas penerangan setempat pada sembilan home industry batik tulis Jetis, Sidoarjo tidak memenuhi standar. Padahal intensitas penerangan sangat penting karena penerangan yang buruk dapat mengakibatkan kelelahan mata dengan berkurangnya daya efisiensi kerja, kelelahan mental, kerusakan indera penglihatan dan meningkatnya kecelakaan kerja (Suma'mur, 2009). Jika penerangan terlalu besar atau terlalu kecil, maka akan menyebabkan pupil mata berusaha menyesuaikan cahaya yang dapat diterima oleh mata. Pupil akan mengecil jika menerima cahaya yang lebih besar dan begitu pula sebaliknya. Hal inilah yang merupakan salah satu penyebab timbulnya kelelahan mata (Depkes, 2008).

Kelelahan mata merupakan salah satu dampak negatif bagi kesehatan yang dapat terjadi pada pengrajin batik tulis. Namun dalam kenyataannya dampak yang seperti ini cenderung kurang diperhatikan. Hal ini karena baik pengusaha maupun pengrajin belum memahami adanya hubungan yang erat antara kondisi kesehatan dan tinggi rendahnya produktivitas. Jika pengrajin mengalami kelelahan mata, maka secara tidak langsung hal ini akan mempengaruhi produktivitas kerjanya. Apabila produktivitas menurun, maka produk yang dihasilkan juga akan menurun kualitas maupun kuantitasnya. Dimana apabila produk uang dihasilkan tersebut menurun kualitas maupun kuantitasnya, maka permintaan konsumen akan produk tersebut akan menurun. Sehingga pemasukan atau pendapatan bagi produsen maupun pengrajin batik tulis pun juga akan menurun.

Penelitian ini bertujuan untuk menganalisis hubungan intensitas penerangan dengan kelelahan mata pada pengrajin batik tulis.

\section{METODE}

Apabila ditinjau dari cara analisis datanya, penelitian ini merupakan penelitian deskriptif karena penelitian diarahkan untuk memberikan gambaran atau deskripsi tentang suatu keadaan secara objektif. Apabila ditinjau dari cara pengambilan datanya, penelitian ini merupakan penelitian observasional. Lalu apabila ditinjau dari segi waktu pengambilan 
datanya, penelitian ini termasuk penelitian cross sectional karena observasi dan pengambilan datanya dilakukan sekaligus pada saat yang sama (Notoatmodjo, 2002).

Penelitian ini dilakukan di sembilan home industry batik tulis yang berada di daerah Kampung Batik Jetis, Sidoarjo. Sedangkan waktu penelitiannya dilaksanakan pada bulan Oktober 2014 sampai Mei 2015.

Populasi dalam penelitian ini adalah semua pengrajin batik tulis di beberapa home industry batik tulis di daerah kampung batik Jetis, Sidoarjo. Terdapat sembilan home industry yang akan dijadikan sebagai objek penelitian, diantaranya batik Amri Jaya, batik H.I, batik Amali C.H, batik Kamzatun, batik Amri, batik Rahmad, batik Namiroh, batik Dunia Wanita, dan batik Murni Artis.

Sampel yang digunakan dalam penelitian ini adalah total populasi yang berjumlah 20 orang dengan kriteria inklusi, hanya untuk pengrajin batik tulis yang menyelesaikan semua pekerjaannya di home industry batik tulis yang bertempat di daerah kampung batik Jetis, Sidoarjo serta tidak menderita penyakit katarak

Terdapat dua macam variabel penelitian yang digunakan yaitu variabel independen dan variabel dependen. Variabel independen meliputi usia, lama kerja, masa kerja, intensitas penerangan di tempat kerja (meliputi sumber penerangan, sistem penerangan buatan, intensitas penerangan, serta daya pantul lantai) dan variabel dependennya yaitu kelelahan mata.

Data yang digunakan dalam penelitian ini ada 2 macam yaitu data primer dan data sekunder. Data primer dalam penelitian ini merupakan data yang diperoleh secara langsung dari sumber data yang didapatkan dengan cara pengukuran intensitas penerangan, pengukuran daya pantul, pengukuran kelelahan mata, serta melakukan observasi sumber penerangan dan sistem penerangan buatan.

Pengukuran intensitas penerangan saat pekerjaan berlangsung. Berikut prosedur pengukuran intensitas penerangan di tempat kerja: nyalakan semua lampu (sumber cahaya), tentukan5 titik lokasi pengukuran tempat kerja, letakkan alat pengukur pada titik-titik lokasi pengukuran, arahkan alat pengukur (cell) menghadap ke sumber cahaya (ke atas), tunggu hingga angka yang tertera pada display stabil, lalu catat hasil pengukuran, hasil pengukuran di rata-rata, bandingkan dengan standar yang berlaku.

Pengukuran daya pantul lantai, dilakukan dengan langkah-langkah berikut: ukur intensitas cahaya yang jatuh pada lantai dengan luxmeter menghadap ke sumber cahaya seperti pengukuran intensitas penerangan lokal. Hasil pengukuran diberi lambing "A Lux", lalu photocell dibalik, kemudian tarik pelanpelan sampai angka level meter konstan.

Hasil pengukuran diberi lambing "B Lux". Pengukuran reflektan dapat dihitung dengan menggunakan rumus:

$$
\mathrm{B} / \mathrm{A} \times 100 \%=\ldots . . \% \text {. }
$$

Pengukuran kelelahan mata dilakukan dengan menggunakan metode Photo stress Recovery Time. Pengukuran ini dilakukan oleh dokter spesialis mata beserta para asistennya. Berikut prosedur pengukurannya: salah satu mata responden ditutup, mata responden yang tidak tertutup, disinari dengan lampu senter atau penlight berkekuatan 3 volt dengan jarak $2 \mathrm{~cm}$ (dilakukan secara bergantian pada mata kanan dan mata kiri), penyinaran dilakukan di depan kornea mata selama 10 detik, setelah lampu senter dimatikan, responden diminta membaca huruf atau angka pada kartu snellen dari jarak 6 meter, dimulai dari huruf yang paling atas hingga yang paling bawah sampai yang bersangkutan dapat membaca segera dengan benar, lama waktu yang diperlukan sejak lampu senter dimatikan sampai dengan kembalinya kemampuan untuk membaca minimal 3 huruf pada tingkat yang telah ditentukan, disebut Recovery Time (RT), recovery Time (RT) dihitung dengan menggunakan stopwatch dalam satuan detik (sekon).

Observasi sumber penerangan dan sistem penerangan buatan di tempat kerja dengan menggunakan lembar observasi. Pengumpulan data sekunder sendiri diperoleh dengan melihat tugu yang dipasang di awal pintu masuk kampung batik Jetis, Sidoarjo. Tugu tersebut berisikan mengenai sejarah didirikannya kampung batik tulis Jetis, Sidoarjo.

Teknik analisis data dilakukan secara deskriptif dalam bentuk tabel frekuensi. Sedangkan untuk mengetahui kuat hubungan antara 2 variabel menggunakan tabulasi silang dan chi square dengan melihat koefisien korelasinya.

Tabel 1. Interval Koefisien dan Tingkat Hubungan

\begin{tabular}{cc}
\hline Interval Koefisien & Tingkat Hubungan \\
\hline $0,00-0,19$ & Sangat rendah \\
$0,20-0,39$ & Rendah \\
$0,40-0,59$ & Sedang \\
$0,60-0,79$ & Kuat \\
$0,80-1,00$ & Sangat kuat \\
\hline
\end{tabular}




\section{HASIL}

\section{Usia}

Usia yang dimaksud dalam penelitian ini adalah jumlah usia mulai lahir sampai diadakannya penelitian ini. Hasil penelitian menunjukkan bahwa dari ketiga kategori usia dari pengrajin batik tulis, ternyata yang mengalami kelelahan mata terbanyak adalah pengrajin yang berusia $<45$ tahun.

Tabel 2. Hubungan Usia dengan Kelelahan Mata pada Pengrajin Batik Tulis Jetis, Sidoarjo Tahun 2015

\begin{tabular}{lccc}
\hline \multirow{2}{*}{$\begin{array}{c}\text { Usia } \\
\text { (tahun) }\end{array}$} & \multicolumn{2}{c}{ Kelelahan Mata } & \multirow{2}{*}{ Total } \\
\cline { 2 - 3 } & Tidak Lelah & Lelah & \\
\hline$<45$ & 2 & 4 & 6 \\
$45-50$ & 3 & 3 & 6 \\
$>50$ & 5 & 3 & 8 \\
\hline Total & 10 & 10 & 20 \\
\hline
\end{tabular}

Hasil dari uji statistik menunjukkan bahwa nilai dari koefisien contingency sebesar 0,235 . Hal ini menunjukkan bahwa antara usia dengan kelelahan mata tingkat hubungannya rendah.

\section{Lama Kerja}

Hasil penelitian terhadap lama kerja didapatkan bahwa dari ketiga kategori lama kerja pada pengrajin batik tulis, ternyata pengrajin tulis yang mengalami kelelahan mata terbanyak yang lama kerjanya $<8$ jam per hari.

Tabel 3. Hubungan Lama Kerja dengan Kelelahan Mata pada Pengrajin Batik Tulis Jetis, Sidoarjo Tahun 2015

\begin{tabular}{lccc}
\hline \multirow{2}{*}{$\begin{array}{c}\text { Lama Kerja } \\
\text { (jam) }\end{array}$} & \multicolumn{2}{c}{ Kelelahan Mata } & \multirow{2}{*}{ Total } \\
\cline { 2 - 3 } & Tidak Lelah & Lelah & \\
\hline$<8$ & 0 & 8 & 8 \\
8 & 6 & 1 & 7 \\
$>8$ & 4 & 1 & 5 \\
\hline Total & 10 & 10 & 20 \\
\hline
\end{tabular}

Hasil uji statistik menunjukkan bahwa nilai dari koefisien contingency sebesar 0,633 . Hal ini menunjukkan bahwa antara lama kerja dengan kelelahan mata tingkat hubungannya kuat.

\section{Masa Kerja}

Masa kerja yang dimaksud dalam penelitian ini adalah lamanya pengrajin batik tulis bekerja di home industry tersebut hingga dilaksanakannya penelitian.
Dari kedua kategori masa kerja pada pengrajin batik tulis yaitu kategori $>3$ tahun dan kategori $<3$ tahun, didapatkan hasil bahwa ternyata pengrajin batik tulis yang mengalami kelelahan mata terbanyak adalah pengrajin batik tulis yang masa kerjanya $>3$ tahun.

Hasil uji statistik menunjukkan bahwa nilai dari koefisien contingency sebesar 0,500 . Hal ini menunjukkan bahwa antara masa kerja dengan kelelahan mata tingkat hubungannya sedang.

\section{Intensitas Penerangan di Tempat Kerja}

\section{Sumber Penerangan}

Sumber penerangan merupakan salah satu komponen supaya para tenaga kerja dapat melakukan pekerjaannya dengan jelas, cepat, nyaman, dan aman. Seluruh sumber penerangan yang digunakan oleh beberapa home industry batik tulis Jetis, Sidoarjo adalah sumber penerangan campuran yaitu gabungan antara sumber penerangan alami dan buatan.

Sumber penerangan alami berasal dari sinar matahari secara langsung. Sumber penerangan buatan merupakan sumber penerangan yang berasal dari lampu.

\section{Sistem Penerangan Buatan}

Seluruh sistem penerangan buatan yang digunakan oleh beberapa home industry batik tulis Jetis, Sidoarjo adalah sistem penerangan buatan jenis direct lighting. Pada sistem direct lighting, 90\% cahaya didistribusikan menuju ke bawah.

Sistem penerangan ini merupakan yang paling efisien dan ekonomis untuk ruangan yang tinggi dan luas. Kekurangan dari sistem ini biasanya menimbulkan kesilauan dan bayangan bagi pekerja. Berikut penjabaran komponen dari sistem penerangan buatan:

\section{Jenis Lampu}

Sistem penerangan buatan, penggunaan lampu merupakan salah satu sumber penerangan alternatif apabila penerangan alami tidak bisa memenuhi kebutuhan. Terdapat dua Jenis lampu yang digunakan di beberapa home industry batik tulis Jetis, Sidoarjo yaitu jenis lampu neon panjang dan lampu neon lilin. Hasil penelitian didapatkan hasil bahwa jenis lampu terbanyak yang digunakan oleh beberapa home indusry batik tulis Jetis, Sidoarjo adalah jenis lampu neon lilin dengan jumlah $95,0 \%$. Hal ini berarti kecenderungan para pemilik home industry untuk menggunakan jenis lampu neon lilin lebih besar daripada menggunakan lampu neon panjang. 


\section{Tegangan Lampu}

Tegangan lampu yang dihasilkan tergantung dari jenis lampu yang digunakan. Terdapat 2 macam tegangan lampu yang digunakan pada beberapa home industry batik tulis Jetis, Sidoarjo yaitu tegangan 40 watt dan tegangan 20 watt.

Tegangan lampu yang kecil akan membuat kondisi lingkungan kerja menjadi tidak kondusif. Hal tersebut dikarenakan pekerja harus berupaya lebih keras lagi untuk melihat objek pekerjaannya. Namun sebaliknya apabila tegangan lampu terlalu besar, maka dapat mengakibatkan mata bekerja lebih keras pula.

Hasil penelitian menunjukkan hasil bahwa ternyata besar tegangan lampu yang paling banyak digunakan oleh beberapa home industry batik tulis Jetis, Sidoarjo adalah 20 watt yaitu sebanyak 95\%. Hal ini menunjukkan bahwa kecenderungan pemakaian tegangan lampu 20 watt paling banyak diminati daripada tegangan lampu 40 watt.

\section{Jumlah lampu yang mati}

Intensitas penerangan buatan merupakan penunjang terpenuhinya intensitas penerangan pada suatu ruangan. Apabila intensitas penerangan pada suatu ruangan tidak terpenuhi maka kemungkinan para pekerja untuk mengalami kecelakaan kerja pun akan semakin besar.

Jumlah lampu yang mati merupakan salah satu faktor yang dapat mempengaruhi intensitas penerangan buatan. Pada penelitian yang dilakukan di beberapa home industry batik tulis Jetis, Sidoarjo didapatkan hasil bahwa tidak ada satu pun lampu yang mati pada semua home industry batik tulis Jetis, Sidoarjo. Hal ini menunjukkan bahwa home industry batik tulis Jetis, Sidoarjo sudah sesuai untuk kategori lampu yang harusnya hidup semua (tidak mati).

\section{Keadaan Lampu}

Keadaan lampu pada suatu ruangan juga dapat menjadi salah satu faktor yang mempengaruhi pada intensitas penerangan buatan. Terdapat beberapa kondisi lampu yang dapat ditemui adalah keadaan lampu yang bersih, sedang, dan kotor.

Penelitian yang dikerjakan pada beberapa rumah industri batik tulis Jetis Sidoarjo, diperoleh hasil bahwa kondisi lampu di seluruh home industry batik tulis Jetis Sidoarjo dapat dikategorikan dalam kondisi sedang. Dikatakan kategori sedang karena secara visual keadaan lampu dipenuhi oleh sarang laba-laba sebanyak 50\% sehingga hampir setengah dari lampu tersebut terdapat laba-laba yang dapat mempengaruhi intensitas penerangan pada lingkungan kerja.

\section{Intensitas Penerangan}

Intensitas penerangan merupakan salah satu komponen supaya para tenaga kerja dapat melakukan pekerjaannya/mengamati objek pekerjaan yang sedang dikerjakan secara jelas, cepat, nyaman, dan aman. Intensitas penerangan di tempat kerja harus memadai dan sesuai dengan standar supaya pada saat para tenaga kerja melakukan pekerjaannya, tidak sampai menimbulkan risiko yang dapat membahayakan para tenaga kerja tersebut.

Intensitas penerangan yang diukur pada penelitian ini adalah intensitas penerangan setempat. Intensitas penerangan setempat merupakan penerangan yang diletakkan tepat di mana para pekerja melakukan pekerjaannya. Pengukuran pada intensitas penerangan setempat dilakukan dengan menggunakan alat yang bernama luxmeter.

Intensitas penerangan yang ada di beberapa home industry terdiri dari berbagai variasi nilai yang berdasarkan pada hasil pengukuran tersebut. Hasil pengukuran intensitas penerangan setempat pada home industry batik tulis Jetis, Sidoarjo dapat diketahui melalui Tabel 4.

Berdasarkan hasil pengukuran intensitas penerangan setempat yang terdapat pada Tabel 4 dapat disimpulkan bahwa masih terdapat banyak home industry batik tulis Jetis, Sidoarjo yang tidak memenuhi standar penerangan setempat (local) yaitu sebesar 55\%. Hal ini menunjukkan bahwa perlu adanya upaya penanggulangan untuk home industry yang masih tidak memenuhi standar supaya lingkungan kerja pada Sembilan home industry tersebut dapat kondusif dan pengrajin dapat bekerja secara produktif.

\section{Daya Pantul Lantai}

Cahaya mengenai objek yang kasar dan hitam maka seluruh cahaya akan diserap, namun apabila permukaannya halus dan mengkilap maka cahaya yang dipantulkan berbentuk sejajar. Apabila permukaan objek tidak rata maka pantulan cahaya akan mengalami diffusi. Untuk mengukur reflektifitas pada lantai yang dihasilkan dari pengukuran dengan memakai luxmeter. Hasil yang dipantulkan sejajar bila permukaan rata, jika permukaan tidak rata maka pantulan cahaya 
Tabel 4. Hasil Dari Pengukuran Intensitas Penerangan Setempat pada Beberapa Home Industry Batik Tulis Jetis, Sidoarjo pada Tahun 2015

\begin{tabular}{|c|c|c|c|}
\hline Home Industry & $\begin{array}{c}\text { Intensitas Penerangan } \\
\text { Setempat (Local) }\end{array}$ & $\begin{array}{l}\text { Standar menurut } \\
\text { UNEP (lux) }\end{array}$ & Keterangan \\
\hline $\mathrm{A}$ & $232 \operatorname{lux}$ & 500 & Tidak Memenuhi \\
\hline $\mathrm{B}_{1}$ & 510 lux & 500 & Memenuhi \\
\hline $\mathrm{B}_{2}$ & 518 lux & 500 & Memenuhi \\
\hline $\mathrm{B}_{3}$ & 523 lux & 500 & Memenuhi \\
\hline $\mathrm{C}$ & 118 lux & 500 & Tidak Memenuhi \\
\hline $\mathrm{D}_{1}$ & 535 lux & 500 & Memenuhi \\
\hline $\mathrm{D}_{2}$ & $532 \operatorname{lux}$ & 500 & Memenuhi \\
\hline $\mathrm{E}_{1}$ & $122 \operatorname{lux}$ & 500 & Tidak Memenuhi \\
\hline$E_{2}$ & 301 lux & 500 & Tidak Memenuhi \\
\hline $\mathrm{F}_{1}$ & $151 \operatorname{lux}$ & 500 & Tidak Memenuhi \\
\hline $\mathrm{F}_{2}$ & $129 \operatorname{lux}$ & 500 & Tidak Memenuhi \\
\hline $\mathrm{G}_{1}$ & 314 lux & 500 & Tidak Memenuhi \\
\hline $\mathrm{G}_{2}$ & 323 lux & 500 & Tidak Memenuhi \\
\hline $\mathrm{G}_{3}$ & 305 lux & 500 & Tidak Memenuhi \\
\hline $\mathrm{G}_{4}$ & $309 \operatorname{lux}$ & 500 & Tidak Memenuhi \\
\hline $\mathrm{H}$ & $108 \operatorname{lux}$ & 500 & Tidak Memenuhi \\
\hline $\mathrm{I}_{1}$ & $539 \operatorname{lux}$ & 500 & Memenuhi \\
\hline $\mathrm{I}_{2}$ & 524 lux & 500 & Memenuhi \\
\hline $\mathrm{I}_{3}$ & 547 lux & 500 & Memenuhi \\
\hline $\mathrm{I}_{4}$ & $521 \operatorname{lux}$ & 500 & Memenuhi \\
\hline
\end{tabular}

menjadi diffusi. Dalam mengukur reflektivitas lantai yang dihasilkan dari luxmeter menunjukkan hasil bervariasi sekitar 8,8-23,14\%.

Pengukuran daya pantul lantai ini, standar yang digunakan yaitu $20 \%$. Apabila pengukuran terhadap daya pantul lantai (reflektivitas) masih di bawah ataupun sama dengan standar yaitu $20 \%$. Maka dapat dikatakan bahwa hasil pengukuran daya pantul lantai tersebut masih memenuhi standar.

Hasil pengukuran dari daya pantul lantai dapat disimpulkan bahwa kebanyakan dari beberapa home industty batik tulis Jetis, Sidoarjo tidak memenuhi standar daya pantul lantai yaitu sebanyak $55 \%$. Hal ini karena warna dari lantai pada home industry batik tulis Jetis, Sidoarjo yang mayoritas gelap dan cenderung kotor. Kurangnya perawatan dan tidak menjaga kebersihan lantai merupakan salah satu faktor yang menyebabkan daya pantul lantai tidak memenuhi standar.

\section{Kelelahan Mata}

Pengukuran kelelahan mata dilakukan dengan menggunakan metode Photostress Recovery Time.

Di mana pengukuran harus dilakukan oleh dokter spesialis mata. Hal ini karena mata nantinya akan disinari dengan penlight selama beberapa detik. Apabila salah dalam melakukan penyinaran,
Tabel 5. Hasil Pengukuran Kelelahan Mata pada Pengrajin Batik Tulis Jetis, Sidoarjo Tahun 2015

\begin{tabular}{ccl}
\hline \multicolumn{2}{c}{ Hasil Pengukuran Kelelahan } \\
Mata & \\
\cline { 1 - 2 } (Detik) & $\begin{array}{c}\text { Mata Kanan } \\
\text { (Detik) }\end{array}$ & \\
\cline { 1 - 2 } 51,87 & 51,75 & Lelah mataki \\
29,07 & 24,91 & Tidak lelah mata \\
32,82 & 48,19 & Tidak lelah mata \\
40,67 & 43,10 & Tidak lelah mata \\
53,81 & 53,59 & Lelah mata \\
10,15 & 9,38 & Tidak lelah mata \\
40,50 & 41,71 & Tidak lelah mata \\
7,50 & 10,50 & Tidak lelah mata \\
50,10 & 50,45 & Lelah mata \\
51,50 & 50,15 & Lelah mata \\
52,50 & 58,50 & Lelah mata \\
50,15 & 51,25 & Lelah mata \\
51,15 & 50,75 & Lelah mata \\
51,00 & 50.45 & Lelah mata \\
55,19 & 50,52 & Lelah mata \\
51,35 & 51,50 & Lelah mata \\
30,34 & 27,85 & Tidak lelah mata \\
27,67 & 31,27 & Tidak lelah mata \\
35,60 & 29,65 & Tidak lelah mata \\
35,00 & 34,60 & Tidak lelah mata \\
\hline & &
\end{tabular}


dikhawatirkan dapat mempengaruhi jaringan lainnya di sekitar mata.

Batas normal mata seseorang dikatakan normal apabila hasil pengukurannya menunjukkan hasil $<50$ detik (sekon). Sehingga apabila hasil pengukurannya $>50$ detik (sekon), maka hasil tersebut dikategorikan ke dalam kategori mengalami kelelahan mata.

Hasil pengukuran kelelahan mata yang didapatkan setelah dilakukan pengukuran pada pengrajin batik tulis yang memenuhi kriteria inklusi memiliki variasi hasil yang cukup signifikan.

Hasil pengukuran tersebut dapat dilihat pada tabel 5. Berdasarkan hasil pengukuran kelelahan mata yang terdapat pada tabel dapat disimpulkan bahwa jumlah pengrajin batik tulis yang tidak mengalami kelelahan mata dengan yang mengalami kelelahan mata seimbang jumlahnya yaitu $50 \%$.

Hubungan Antara Intensitas Penerangan dengan Kelelahan Mata Pada Pengrajin Batik. Hubungan intensitas penerangan dengan kelelahan mata dapat diketahui pada tabel ini:

Tabel 6. Hubungan Antara Intensitas Penerangan dengan Kelelahan Mata pada Pengrajin Batik Tulis Jetis di Sidoarjo Tahun 2015

\begin{tabular}{lccr}
\hline \multicolumn{1}{c}{$\begin{array}{c}\text { Intensitas } \\
\text { Penerangan } \\
\text { Setempat }\end{array}$} & $\begin{array}{c}c \\
\text { Tidak } \\
\text { lelah }\end{array}$ & Lelah & Total \\
\hline Tidak memenuhi & 1 & 10 & 11 \\
Memenuhi & 9 & 0 & 9 \\
\hline Total & 10 & 10 & 20 \\
\hline
\end{tabular}

Hasil dari uji statistik tersebut diketahui bahwa nilai dari koefisien Cramer's $V$ sebesar 0,905. Maka antara intensitas penerangan dengan kelelahan mata tingkat memiliki hubungan sangat kuat.

Hasil tersebut menunjukkan bahwa penerangan dapat menentukan kualitas objek yang akan menjadi sasaran penglihatan. Maka dari hasil penelitian memberikan hasil penerangan berpengaruh signifikan terhadap kelelahan mata.

\section{PEMBAHASAN}

\section{Usia}

Menurut NASD (National Aging Safety Database) dalam Maryamah (2011) menyatakan bahwa usia seseorang yang semakin tua memiliki pengaruh pada kemunduran kemampuan penglihatan dalam setiap objek lingkungan sekitar. Ketika usia 20 tahun rata-rata manusia dapat melihat objek dengan jelas. Sedangkan pada usia 45-50 tahun dan memiliki kebutuhan cahaya $4 x$ jauh lebih besar, sedangkan pada usia 60 tahun, kebutuhan akan cahaya jauh lebih besar lagi.

Hasil dari uji chi square menunjukkan bahwa nilai dari koefisien contingency sebesar 0,235 . Hal ini menunjukkan bahwa antara usia dengan kelelahan mata tingkat hubungannya rendah. Hasil penelitian ini sejalan dengan penelitian yang dilakukan oleh Mayasari (2009) yang menyatakan bahwa terdapat hubungan yang rendah antara keluhan kelelahan mata dengan umur yaitu dengan nilai koefisien contingency sebesar 0,316 .

Namun, penelitian ini berbeda dengan penelitian yang dilakukan oleh Rohman (2014) yang menyatakan bahwa terdapat hubungan yang kuat (signifikan) antara umur dengan penurunan tajam penglihatan mata kanan dan kiri.

\section{Lama Kerja}

Pheasant (1991) berpendapat bahwa kegiatankegiatan yang menggunakan otot-otot mata adalah sumber utama keluhan eyestrain. Sedangkan faktor yang mempunyai pengaruh besar adalah pekerjaan pada jarak dekat yang dilakukan pada kurun waktu yang lama.

Mayoritas pengrajin batik tulis yang mengalami kelelahan mata adalah pengrajin yang lama kerjanya $<8$ jam per hari. Berdasarkan uji statistik diketahui bahwa nilai dari koefisien contingency sebesar 0,633 . Hal ini menunjukkan bahwa antara lama kerja dengan kelelahan mata tingkat hubungannya kuat. Hasil penelitian ini berbeda dengan penelitian yang dilakukan oleh Mayasari (2009) yang menyatakan bahwa terdapat hubungan yang rendah antara keluhan kelelahan mata dengan jam kerja dalam sehari yaitu dengan nilai koefisien contingency sebesar 0,235.

\section{Masa Kerja}

Pada Encyclopedia of Occupational and Safety (1998), terdapat keluhan gangguan pada mata rata-rata yang dirasakan setelah pekerja yang bekerja selama 3-4 tahun untuk pekerjaan yang membutuhkan ketelitian. Para pekerja yang lebih dari tiga tahun akan memiliki tingkat risiko yang lebih cepat mengalami kelelahan mata jika dibandingkan dengan para pekerja yang masa kerja kurang dari atau sama dengan tiga tahun. Dari hasil penelitian yang dilakukan diketahui bahwa pengrajin yang mayoritas mengalami kelelahan mata adalah pengrajin yang masa kerjanya $>3$ tahun. 
Hasil dari uji statistik menunjukkan bahwa nilai dari koefisien contingency sebesar 0,500 . Hal ini menunjukkan bahwa antara masa kerja dengan kelelahan mata tingkat hubungannya sedang. Hasil penelitian ini berbeda dengan penelitian yang dilakukan oleh Rohman (2014), yang menyatakan bahwa masa kerja dengan penurunan tajam penglihatan memiliki hubungan tingkat keeratan yang kuat.

\section{Intensitas Penerangan di Tempat Kerja}

Intensitas penerangan yang diperlukan oleh para pengrajin batik tulis adalah intensitas penerangan setempat (local) yang memenuhi standar. Hal ini karena pekerjaan yang dilakukan oleh pengrajin merupakan pekerjaan yang membutuhkan ketelitian yang tinggi. Dari hasil pengukuran intensitas penerangan menunjukkan hasil bahwa masih banyak home industry batik tulis Jetis, Sidoarjo yang tidak memenuhi standar penerangan setempat (local) yaitu sebanyak 55\%. Berdasarkan standar kebutuhan penerangan untuk industri tekstil menurut UNEP untuk pekerjaan pewarnaan yang membutuhkan ketelitian tinggi (akurat), rekomendasi yang disarankan yaitu sebesar 500 lux.

Penerangan setempat yang tidak memenuhi standar pada beberapa home industry batik tulis Jetis, Sidoarjo dipengaruhi oleh beberapa faktor mengenai dekorasi tempat kerja, diantaranya:

\section{Dinding}

Dinding pada beberapa home industry batik tulis semuanya terbuat dari bahan batu bata dengan dominasi warna dinding yang tergolong cerah sebesar $90 \%$. Namun untuk kondisi dinding masih banyak yang termasuk dalam kategori sedang yaitu sebesar $70 \%$. Sehingga meskipun warna dinding awalnya cerah akan berubah menjadi gelap seiring berjalannya waktu. Hal inilah yang menyebabkan intensitas penerangan setempat tidak memenuhi standar, karena warna dinding yang gelap dapat menurunkan efektivitas dari instalasi penerangan sebanyak 50\% (Siswanto, 1989).

\section{Langit-langit}

Langit-langit pada beberapa home industry batik tulis mayoritas terbuat dari genteng yaitu sebesar $35 \%$. Dominasi warna langit-langit adalah gelap ditambah dengan kondisi langit-langit mayoritas dalam kondisi kotor. Hal inilah yang menyebabkan intensitas penerangan setempat tidak memenuhi standar, karena warna langit-langit yang gelap dapat menurunkan efektivitas dari instalasi penerangan sebanyak 50\% (Siswanto, 1989).

\section{Lantai}

Lantai pada beberapa home industry batik tulis mayoritas terbuat dari keramik yaitu sebesar $65 \%$ dengan warna lantai yang gelap dan termasuk dalam kategori kotor. Hal inilah yang menyebabkan intensitas penerangan setempat tidak memenuhi standar, karena warna lantai yang gelap dapat menurunkan efektivitas dari instalasi penerangan sebanyak 50\% (Siswanto, 1989). Selain itu, nilai pantulan lantai mayoritas beberapa home industry batik tulis Jetis, Sidoarjo tidak memenuhi standar daya pantul lantai yaitu sebanyak $55 \%$.Berdasarkan standar daya pantul lantai menurut Santoso (2004), daya pantul lantai yang baik seharusnya memiliki nilai $20 \%$.

Selain dipengaruhi oleh faktor mengenai dekorasi tempat kerja, intensitas penerangan setempat (local) pada beberapa home industry batik tulis Jetis, Sidoarjo juga dipengaruhi komponen lain seperti:

\section{Sumber Penerangan}

Sumber penerangan merupakan salah satu komponen supaya para tenaga kerja dapat melakukan pekerjaannya dengan jelas, cepat, nyaman, dan aman. Seluruh sumber penerangan yang digunakan oleh beberapa home industry batik tulis Jetis, Sidoarjo adalah sumber penerangan campuran yaitu gabungan antara sumber penerangan alami dan buatan. Meskipun beberapa home industry batik tulis Jetis, Sidoarjo sudah banyak yang menggunakan sumber penerangan campuran namun masih banyak home industry yang tidak memenuhi standar. Hal ini karena besar atau banyaknya cahaya yang terdapat pada tempat yang satu dengan yang lain berbedabeda dan dipengaruhi beberapa faktor lain.

\section{Sistem Penerangan Buatan}

Seluruh sistem penerangan buatan yang digunakan oleh beberapa home industry batik tulis Jetis, Sidoarjo adalah sistem penerangan buatan jenis direct lighting. Pada sistem direct lighting, 90\% cahaya didistribusikan menuju ke bawah. Meskipun begitu masih banyak home industry yang tidak memenuhi standar. Berikut penjabaran komponen dari sistem penerangan buatan: 


\section{Jenis Lampu}

Jenis lampu yang digunakan oleh beberapa home industry batik tulis Jetis, Sidoarjo adalah jenis lampu neon (lampu pelepasan listrik bertekanan rendah). Lampu jenis ini merupakan jenis lampu yang memiliki berbagai keunggulan yaitu efisiensi yang tinggi, kesilauan yang rendah, tidak banyak bayangan, suhu rendah, terdapat dalam berbagai warna, tidak menimbulkan distorsi warna objek yang diamati (Silalahi, 1995). Namun, tingkat intensitas penerangan yang dihasilkan oleh lampu juga dipengaruhi tegangan dan kondisi lampu tersebut.

\section{Tegangan Lampu}

Mayoritas home industry batik tulis Jetis, Sidoarjo menggunakan lampu neon bertegangan 20 watt. Tegangan lampu sebesar 20 watt ini masih belum bisa mencukupi kebutuhan intensitas penerangan setempat mengingat dinding, langitlangit, dan lantai di sana masih dalam kondisi gelap dan kotor. Hal inilah yang menyebabkan intensitas penerangan setempat tidak memenuhi standar karena warna dinding, langit-langit, dan lantai yang gelap dapat menurunkan efektivitas dari instalasi penerangan sebanyak 50\% (Siswanto, 1989). Sehingga tegangan lampu yang awalnya 20 watt, akan menjadi semakin kecil karena mengalami penurunan sebesar $50 \%$.

\section{Keadaan Lampu}

Keadaan lampu pada semua home industry batik tulis Jetis, Sidoarjo termasuk dalam keadaan lampu dengan kategori sedang. Ditambah dengan kurangnya perawatan, keadaan lampu yang sudah termasuk dalam kategori sedang, lambat laun akan menjadi kotor. Mengingat komposisi warna yang dihasilkan lampu neon tergantung zat-zat fluorescent yang melapisi bagian dalam lampu tersebut (Silalahi, 1995). Keadaan lampu bagian luar yang kotor ini pun akhirnya juga akan menghalangi intensitas penerangan yang dihasilkan oleh lampu tersebut.

\section{Hasil Pengukuran Kelelahan Mata}

Kelelahan mata adalah lelahnya otot-otot mata akibat penggunaan mata untuk melihat dengan jarak dekat, berkonsentrasi, atau, terlalu fokus pada objek yang cenderung tidak nyaman untuk dilihat dalam kurun waktu yang lama (Setiawan, 2012). Selain itu, kelelahan mata disebabkan oleh stress yang terjadi pada fungsi penglihatan. Stress pada otot yang berfungsi untuk akomodasi dapat terjadi pada saat seseorang berupaya untuk melihat pada objek yang berukuran kecil dan pada jarak yang dekat dalam jangka waktu yang relative lama. Pada kondisi seperti itu, otot-otot mata akan bekerja secara terus-menerus dan lebih dipaksakan. Ketegangan otot-otot pengakomodasi (korpus siliaris) semakin besar sehingga terjadi peningkatan asam laktat dan sebagai akibatnya terjadi kelelahan mata. Stress pada retina dapat terjadi apabila terdapat kontras yang berlebihan dalam lapangan penglihatan dan waktu pengamatan yang relatif lama (Soewarno, 1992).

Hasil dari pengukuran mata yang terdapat pada tabel dapat disimpulkan bahwa jumlah pengrajin batik tulis yang tidak mengalami kelelahan mata dengan yang mengalami kelelahan mata jumlahnya seimbang yaitu sebanyak $50 \%$. Hal ini tidak sejalan apabila dibandingkan dengan hasil pengukuran intensitas penerangan yang mayoritas tidak memenuhi standar.

Setelah diperiksa kembali, ternyata terdapat satu orang pengrajin yang tidak mengalami kelelahan mata walaupun intensitas penerangan di tempat kerjanya tidak memenuhi standar. Hal ini karena usia dari pengrajin tersebut masih $<45$ tahun, tepatnya yaitu masih berusia 26 tahun. Menurut Haeny (2009), semakin muda seseorang kebutuhan cahaya akan lebih sedikit dibandingkan dengan usia yang lebih tua dan kecenderungan untuk mengalami kelelahan mata lebih sedikit. Selain itu, masa kerja dari pengrajin tersebut juga tergolong masih belum lama yaitu masih satu tahun. Menurut Encyclopedia of Occupational and Safety (1998), adanya keluhan gangguan pada mata dirasakan setelah pengrajin bekerja dengan masa kerja lebih dari 3-4 tahun. Sehingga apabila pengrajin tersebut masih bekerja selama satu tahun, tidak heran jika pengrajin tersebut tidak mengalami kelelahan mata. Hal ini karena terjadinya kelelahan mata disebabkan oleh banyak faktor.

Menurut Mangoenprasedjo (2005), cara merawat mata agar tidak sampai mengalami kelelahan mata adalah menghindari penerangan buruk pada saat bekerja dan melakukan pemeriksaan mata ke dokter mata secara teratur. Terutama jika mata terlihat merah, berair, dan terasa gatal serta sering mengalami sakit kepala.

\section{Hubungan Intensitas Penerangan dengan Kelelahan Mata}

Penerangan dengan intensitas rendah dapat menyebabkan kelelahan mata, ketegangan mata, dan keluhan pegal di sekitar mata. Namun apabila 
intensitas penerangan tinggi, hal ini juga dapat menimbulkan kesilauan yang dapat mengganggu pekerjaan. Oleh sebab itu harus diupayakan penerangan dengan intensitas yang cukup dan memadai, yaitu tidak terlalu rendah maupun tinggi (Santoso, 2004).

Hasil penelitian menunjukkan bahwa persentase pengrajin yang kondisi intensitas penerangan setempat (local) di area kerjanya dikategorikan tidak memenuhi standar sebesar $55 \%$ dan pengrajin yang kondisi intensitas penerangan setempat (local) di area kerjanya dikategorikan memenuhi standar $45 \%$. Jumlah pengrajin yang intensitas penerangan setempat (local) di area kerjanya dikategorikan tidak memenuhi standar dan mengalami kelelahan mata sebanyak 10 orang. Jumlah ini sangat besar apabila dibandingkan dengan jumlah pengrajin yang intensitas penerangan setempat (local) di area kerjanya dikategorikan memenuhi standar dan mengalami kelelahan mata yaitu sebanyak 0 orang atau tidak ada sama sekali pengrajin yang mengalami kelelahan mata.

Hasil dari uji statistik diketahui bahwa nilai dari koefisien Cramer's V sebesar 0,905. Hal ini menunjukkan bahwa antara intensitas penerangan dengan kelelahan mata tingkat hubungannya sangat kuat. Hasil penelitian ini sejalan dengan penelitian yang dilakukan oleh Hambali (2004), yang menyatakan bahwa terdapat hubungan yang sangat kuat (positif) antara tingkat pencahayaan dengan kelelahan mata.

Hasil penelitian ini berbeda dengan penelitian yang dilakukan oleh Mayasari (2009), yang menyatakan dari hasil perhitungan didapatkan nilai sebesar 0,113 yang menunjukkan bahwa terdapat hubungan yang sangat rendah antara keluhan kelelahan mata dengan intensitas penerangan.

Pencahayaan dapat diatur sesuai dengan kecermatan atau jenis pekerjaan sehingga kesehatan mata dari para tenaga kerja dapat terpelihara dengan baik dan motivasi kerja bisa meningkat (Subaris dan Haryono, 2007). Penerangan yang memadai dapat memudahkan para tenaga kerja untuk melakukan pekerjaannya tanpa harus melakukan upaya berlebih terutama dalam kegiatan melihat objek pekerjaannya (Suma'mur, 2009).

Menurut Santoso (2004), pengendalian yang dapat dilakukan untuk menanggulangi masalah penerangan di tempat kerja terdapat dua macam yaitu secara teknis (peningkatan kebersihan instalasi penerangan tempat kerja termasuk lampu, pengaturan warna dan dekorasi tempat kerja, pemanfaatan cahaya alami semaksimal mungkin) dan secara administrative (pemeriksaan kesehatan mata seperti pemeriksaan sebelum kerja, berkala, maupun pemeriksaan khusus).

\section{SIMPULAN}

Beberapa keterbatasan penelitian yaitu tidak mencantumkan faktor usia dan lama kerja terhadap timbulnya kelelahan mata. Penelitian yang dilakukan pada home industry batik tulis Jetis, Sidoarjo menunjukkan bahwa masih banyak intensitas penerangan setempat yang tidak memenuhi standar penerangan setempat (local). Rata-rata dalam penelitian ini, pengrajin batik tulis yang paling banyak mengalami kelelahan mata adalah pengrajin yang berusia $<45$ tahun, dengan lama kerja $<8$ jam per hari dan yang memiliki masa kerja $>3$ tahun. Jumlah pengrajin batik tulis yang tidak mengalami kelelahan mata dengan yang mengalami kelelahan mata jumlahnya seimbang. Adanya hubungan antara intensitas penerangan dengan kelelahan mata pada pengrajin batik tulis memiliki tingkat hubungan yang sangat kuat.

\section{DAFTAR PUSTAKA}

American Optometric Association (AOA). 2004. Vision USA//http://www.aoafoundation.org/(sitasi 30 Maret 2015).

Depkes.2008.Pecahayaan Salah Perburuk Penglihatan //http://www.klikdokter.com/article/ detail/401.htm (sitasi 07 April 2015).

Encyclopedia of Occupational and Safety. 1998. Part 1 The Body//http://www.ilocis.org/en/ contilo.html (sitasi 27 Maret 2015).

Hanum, Iis Faizah. 2008. Efektivitas Penggunaan Screen pada Monitor Komputer untuk Mengurangi Kelelahan Mata Pekerja Call Centre di PT Indosat Nsr Tahun 2008. Tesis. Medan; Universitas Sumatera Utara.

Koesyanto, Herry. 2006. Pengaruh Penerangan dan Jarak Pandang Pada Komputer terhadap Kelelahan Mata. Jurnal Kemas, 1 (2): 44-51.

Maryamah, Siti. 2011. Faktor-faktor yang Berhubungan dengan Keluhan Kelelahan Mata Pada Pengguna Computer di Bagian Outbond Call Gedung Graha Telkom BSD (Bumi Serpong Damai) Tangerang Tahun 2011. Skripsi. Jakarta, Universitas Islam Negeri Syarif Hidayatullah. 
Mayasari, Eriana Agyustin. 2009. Beberapa Faktor yang Berhubungan Dengan Keluhan Kelelahan Mata Pada Operator Komputer di PT. Indosat Surabaya. Tugas Akhir. Surabaya, Universitas Airlangga.

Notoatmodjo, Soekidjo. 2002. Metodologi Penelitian Kesehatan. Jakarta: PT. Rineka Cipta.

Pheasant, Stephen. 1991. Ergonomics, Works, and Health. USA: Aspen Publisher Inc.

Rohman, Fajar Fatkhur. 2014. Hubungan Tingkat Kedisiplinan Pemakaian Kacamata Las dengan Penurunan Tajam Penglihatan pada Pekerja Pengelasan di Kecamatan Slogohimo Kabupaten Wonogiri. Skripsi. Surakarta, Universitas Muhammadiyah Surakarta.

Santoso, Gempur. 2004. Manajemen Keselamatan \& Kesehatan Kerja. Surabaya: Prestasi Pustaka.

Setiawan, Iwan. 2012. Analisis Hubungan Faktor Karakteristik Pekerja, Durasi Kerja, Alat Kerja, dan Tingkat Pencahayaan dengan Keluhan Subjektif Kelelahan Mata pada Pengguna Komputer di PT. Surveyor Indonesia Tahun 2012. Skripsi. Depok, Universitas Indonesia.

Silalahi, Bennett. 1995. Manajemen Keselamatan dan Kesehatan Kerja. Jakarta: PT. Pustaka Binaman Presindo.
Siswanto. 1989. Penerangan. Surabaya: Balai Hiperkes dan Keselamatan Kerja Jawa Timur.

Soewarno, 1992. Penerangan Tempat Kerja. Jakarta: Pusat Pelayanan Ergonomi dan Kesker.

Subaris, Heru dan Haryono. 2007. Hygiene Lingkungan Kerja. Yogyakarta: Mitra Cendikia Press.

Suma'mur. 2009. Higiene Perusahaan dan Kesehatan Kerja (HIPERKES). Jakarta: Sagung Seto.

Supriati, Febriana. 2012. Faktor-faktor yang berkaitan dengan Kelelahan Mata pada Karyawan Bagian Administrasi di PT. Indonesia Power UBP Semarang. Volume 1. Nomor 2. Page 720-730. http://ejournals1.undip.ac.id/index.php/jkm (sitasi 07 Juli 2015)

Widowati, E. 2009.Pengaruh Intensitas Pencahayaan Lokal. Jurnal Kesehatan Masyarakat. Volume 5. Nomor. 1. Page 64-69. http://journal.unnes.ac.id/ nju/index.php/kemas (sitasi 10 Juli 2015).

Wiyanti, Nina. 2015. Hubungan Intensitas Penerangan dan Jarak Pandang dengan Kelelahan Mata pada Pengrajin Batik Tulis. Skripsi. Surabaya, Universitas Airlangga. 